Article

\title{
Integrating Sustainability in Management Education
}

\author{
Emmanuel Raufflet \\ Department of Management, HEC Montreal, 3000, Cote-Sainte-Catherine, Montreal, Quebec, \\ H3T 2A7, Canada; E-Mail: emmanuel.raufflet@hec.ca; Tel.: +1-514-340-6196; \\ Fax: $+1-514-340-5635$
}

Received: 12 August 2013; in revised form: 27 August 2013 / Accepted: 29 September 2013 /

Published: 14 October 2013

\begin{abstract}
Over the last decade, numerous modules, courses, and programs in Management Education have integrated sustainability into their curricula. However, this "integration" has translated into very diverse forms and contents. This article aims to clarify these ambiguities. It maps four forms of sustainability integration in Management Education. These four distinct forms are (1) discipline-based integration, in which the anchoring point is the business discipline (sustainability is added as a dimension of this body of knowledge); (2) strategic-/competitive-based integration, in which the anchoring point is the strategy of the organization (sustainability is viewed as a potential contributor to the firm's competitive advantage); (3) integration by application, in which managerial tools and approaches from business disciplines are applied so as to contribute to addressing a sustainability challenge; and, last, (4) systemic integration, in which the anchoring point is a social-ecological-economic challenge defined from an interdisciplinary perspective. Implications of this chapter for the design of courses and programs and the practice of sustainability in Management Education are twofold. First, this article contributes to going beyond the prevailing tendency of studies in the field of sustainability in Management Education to focus mainly on tools and applications. In doing so, this article helps frame these challenges on the level of course and program design. Second, this article helps management educators map what they are intending to achieve by the integration of sustainability into the Management Education curriculum.
\end{abstract}

Keywords: sustainability; integration; program design; management education 


\section{Introduction}

Over the last decade, many undergraduate, graduate, and executive business programs have inserted modules, courses, and components having to do with sustainability. Several sustainability-related programs have been created as well (see [1] for an overview of this in the US). Volumes and special issues of journals about these experiences and the lessons learned have been published [2-4] that reflect on this trend. Several forums have been established for Management and Business educators to discuss and exchange experiences, and, more broadly, to reflect on issues related to sustainability in Management Education.

This multiplication and diffusion of courses, modules, and programs has often responded to demands from accreditation bodies (see, among others, the AACSB (American Association of Colleges and Schools of Business) and business organizations, governments, society, and students. On a global level, these efforts have responded to calls from institutions such as the Global Compact and UNESCO, particularly regarding the latter's Decade of Education for Sustainable Development $[5,6]$. Correspondingly, resources for management educators about sustainability-related teaching material have expanded in the form of exercises, teaching cases, simulations, and textbooks, among others (see, for example, Oikos.org and Caseplace.org websites for sustainability-related teaching material).

However, this multiplication of sustainability resources has also led to wide diversity in terms of the topics, levels of analysis and action, format, and pedagogical process of these courses. Concerning the topics covered, sustainability-related courses may range from very technical to integrative areas. In terms of topics, these courses may emphasize environmental, social, or economic issues. Regarding levels of analysis and action, these courses may take place on the individual, group, organizational, inter-organizational, national, or international levels. As regards format, some courses may represent "standalone" attempts or may be part of efforts that are more encompassing to integrate sustainability into a whole curriculum or even to connect it with green-campus movements. Pedagogical approaches to these courses may consist of a process of "transmission absorption" of established knowledge areas. On the other end of the spectrum, approaches may promote the co-construction of knowledge understanding through interactions between instructors and participants, with more emphasis on the delivery process than on content.

The sheer diversity of sustainability-related courses, together with the broad definition of sustainable development, represents a source of inspiration as well as a source of confusion regarding the integration of sustainability. At the end of the introduction to the special issue of Business Strategy and the Environment dedicated to educating for sustainability ([3], p. 145) conclude, "We have come to understand that the undertaking we embarked upon was in some ways daunting." Some dimensions of this "daunting" undertaking for instructors and business educators are related to conceptual questions and to the diversity of programs and experiences observed. On a conceptual level, what does "integrating sustainability in a Management Education" actually mean? Is it about mainstreaming, i.e., inserting/adding sustainability-related issues and topics to more "classical," established Management Education? Or is it about "changing course," i.e., questioning the ideology, assumptions, purpose, content, and process of Management Education in light of sustainability-related challenges [7]? On a pedagogical level, given the diversity of programs, experiences, and learning outcomes, what does sustainability in Management Education actually mean? 
This article aims to shed some light on the conceptual and pedagogical challenges of integrating sustainability in Management Education. Doing so, it proposes a framework to map various forms of integration. The remainder of this article is organized into three sections. The first section identifies frequent conceptual and institutional/organizational challenges related to the integration of sustainable development in Management Education. The second section introduces a framework that maps four forms of sustainability integration in Management Education. The concluding section highlights the potential and possible limitations of this framework for mapping and designing the integration of sustainability in Management Education.

\section{Sustainability and Management Education: Conceptual, Institutional, and Curriculum-Related Challenges}

"Integration" is defined here broadly as the search for coherence in a program or pedagogical activity related to sustainability issues. Sustainability integration in Management Education is a daunting task on conceptual as well as on institutional/organizational levels. The conceptual challenges are due to the various definitions and interpretations of "sustainable development" and "sustainability." The institutional/organizational challenges are a result of the context in which courses and programs are designed, implemented, and delivered, namely the context of business schools and universities / faculties of administration.

\subsection{Conceptual Challenges}

The Brundtland Commission [8] defined sustainable development as a development that "meets the needs of the present without compromising the ability of future generations to meet their own needs." Also, it referred to the "interdependent and mutually reinforcing pillars" of sustainable development as being economic development, social development, and environmental protection. This definition has been criticized for several reasons, such as for favoring humans over ecosystems [9], for relying on a definition of "development" that favors developed parts of the world to the detriment of developing parts of the world [10], and for its unclear definition of "needs", which is most often defined according to ecologically unsustainable and socially disruptive consumption patterns $[11,12]$. This vagueness has led several educators and education scholars to question the relevance of educating individuals and groups towards sustainable development, given that educating towards sustainable development would lead to the subordination of education to the vague and widely contested notion of sustainable development [13].

\subsection{Institutional Challenges}

The second set of challenges concerns the organizational/institutional dimensions of business schools. Critiques of business schools in general and of their curricula in particular are not new. Business schools have been criticized from several angles, including for being centered on functions and specialized expertise to the detriment of management practice per se [14]. Other critiques include their emphasis on the training of individuals towards arrogance and with a limited awareness about social issues [15], and a preference for "scientific" research over practical relevance — which has led to 
a more technical and specialized curriculum, a focus on quantitative approaches [16]. A more recent critique was coined in the documentary Inside $J o b$ [17] which highlighted the ambiguous roles and responsibilities of several US deans of Business Schools and faculty in generating the conditions for the 2008 financial crisis. A last set of obstacles concerns the ethos - the organizational culture - of the academic institution / business school, whose dominant values may be explicitly or implicitly adverse to sustainability-related values [18].

\subsection{Curriculum-Related Challenges}

Challenges concerning integration into the Management Education curriculum are neither new nor specific to sustainability. Béchard [19], in research looking at two decades of forms of integration in the Management Education curriculum, concluded that despite several reports regarding the state of Management Education curriculum that highlights the need for integration, limited progress had been achieved. Several programs have adopted one of the three approaches to inserting sustainability into the curriculum. The first approach consists of creating a course in an existing Management program, with limited connection to the issues of the existing curriculum. This ad hoc approach has been frequently adopted [20]. However, the creation of a course on sustainable development, which may initially appear to be a solution, may not address deeper issues related to the existing curriculum, namely the assumptions of existing programs. Giacalone and Thomson [21] highlighted the difference between implicit and explicit assumptions about business ethics in Management programs. While implicit curriculum refers to the ideology and underlying assumptions of specific courses and disciplines, explicit curriculum refers to formal and deliberate attempts to bring sustainability into classroom conversations and concerns. Therefore, it can be assumed that a sustainability course added onto a program that is dominated by short-term and narrow assumptions would not hit its target [7].

The second option is to redesign the curriculum with sustainability as an anchoring point. Here again, the polymorphous meaning of sustainability may make it difficult to actually anchor a program. As for priorities, educators may find it difficult to select which sustainability topics are most important to address in business curriculum. As for integration of the environmental, social, and economic elements of sustainability, the question is how to ensure that students and managers integrate the relationships among these dimensions into their thinking and actions. As for content, a frequent challenge is to present business students, who are often overspecialized, with the often technically complex topics of energy conservation, climate change, and biodiversity. In general, how does one make sense of and create a coherent course or curriculum out of potentially disparate material?

This first section has discussed the conceptual, institutional, and curriculum-related challenges of integrating sustainability into the Management curriculum. What makes this integration a daunting task is these interrelated dimensions. The polymorphous meaning of sustainability, together with the institutional challenges of business schools and the enduring problem of Management Education curriculum, make this integration difficult. The need for clarification regarding the forms of integration is the purpose of the following section. 


\section{Mapping Forms of Curriculum Integration}

Before mapping forms of integration of sustainability in Management Education, we first need to map Management Education as a field per se. We do so based on epistemological and analytical criteria. On the one hand, from both historical and epistemological perspectives, Management Education is constituted around management disciplines, such as accounting, finance, economics, human resources, etc., and is connected by capstone disciplines such as strategy or strategic management [22,23]. Each of these management disciplines is organized around a common theoretical basis, certain assumptions, and tools that aim to orient and inform managerial and organizational decisions and actions. The disciplinarity (monodisciplinarity $v s$. interdisciplinarity) axis represents the vertical axis for differentiating between places where the integration of sustainability occurs (see Table 1). On the other hand, historically, the unit of analysis of Business/Management Education has been the business organization or corporation. The first business schools - such as the Harvard Business School, HEC Paris, and HEC Montreal, among others-were established at the turn of the twentieth century to meet the needs of companies for qualified accountants, administrators, and managers. The division of knowledge in Management programs typically reflects the functional divisions in the business organization itself. The overarching concern of Management Education is related to managerial action in business organizations. Over the last few years, several Management programs have aimed to train managers in different forms of organizations - such as cooperatives and social economy organizations - and with motives other than profit beyond the "typical" business model (such as social enterprises, social innovation, and social business programs). This innovative, non-business organization-related model and its motivations have become more significant since the 2008 financial and economic crisis, which challenged the dominant model. The second/horizontal axis concerns the unit of analysis per se; it addresses the question, "What unit of analysis is to be sustained?" This axis ranges from the sustainability of a business organization with an overarching concern for its own competitiveness to the realization of the conditions for the sustainability of a society and/or ecosystem. For the sake of clarity, we label the latter "a social and ecological system" (see Table 1).

Table 1. Four forms of "integration".

\begin{tabular}{|l|l|l|}
\hline Interdisciplinarity & $\begin{array}{l}\text { How does one increase the } \\
\text { sustainability of a business } \\
\text { organization by integrating } \\
\text { different bodies of knowledge? } \\
\text { Strategic/competitive } \\
\text { integration }\end{array}$ & $\begin{array}{l}\text { How does one make social- } \\
\text { ecological-economic systems } \\
\text { more sustainable? } \\
\text { How does one increase the } \\
\text { resilience of systems? } \\
\text { How does one foster social or } \\
\text { institutional innovation? } \\
\text { Systemic integration }\end{array}$ \\
\hline Monodisciplinarity & $\begin{array}{l}\text { How does one insert } \\
\text { sustainability concerns into a } \\
\text { single discipline? } \\
\text { Discipline-based or functional } \\
\text { integration }\end{array}$ & $\begin{array}{l}\text { How does one apply knowledge } \\
\text { and tools from this body of } \\
\text { knowledge to a sustainability- } \\
\text { related issue or situation? } \\
\text { Integration by application }\end{array}$ \\
\hline $\begin{array}{l}\text { Knowledge integration / } \\
\text { Unit of analysis }\end{array}$ & Business organization & $\begin{array}{l}\text { Social-ecological-economic } \\
\text { system }\end{array}$ \\
\hline
\end{tabular}


This matrix summarizes visually the four forms of integration. Each form of integration identified in each quadrant frames the issue of integration in a different way.

The left lower quadrant - discipline-based integration - maps the integration of sustainability from the standpoint of a single discipline and answers the question, "How does one insert sustainability concerns into a single discipline?" An example of the advancement of this mono-disciplinary integration is environmental accounting. Research and teaching in environmental accounting aims to provide models that are adapted to include externalities of business activities, such as pollution or natural resources depletion, into accounting models and decision-making processes.

The lower right quadrant-integration by application - maps the mono-disciplinary integration of sustainability. This application of tools developed in a management discipline aim to address a sustainability conundrum such as changing individual or group behaviors regarding an environmental or social issue. It aims to address the question, "How can management tools contribute to addressing social and environmental systemic challenges?" Social and environmental marketing illustrate this form of integration. For example, cause-marketing aims to sensitize individuals and groups or raise awareness of sustainable development issues, which may lead to behavioral change and, eventually, to social or environmental betterment. This form of applied integration mobilizes tools that were traditionally designed for a business organization and gives them a new purpose, one aligned with social and environmental sustainability.

The upper right quadrant - strategic/competitive integration - maps the integration of sustainability concerns with an exclusive focus on the business organization. Alignment between sustainability and business competitiveness is the underlying postulate of this perspective. This approach assumes that the integration of sustainability concerns will be aligned with improving the competitive position of the business organization either as a strategy to reduce inefficiencies or as a source of product or company differentiation. In other words, this approach assumes that the competitive position of the company may benefit from sustainability concern. This form of integration is interdisciplinary: in contrast to the mono-disciplinary integration observed in disciplines such as accounting or marketing for instance, different disciplines are mobilized, and their respective contributions are mobilized towards the achievement of a sustained competitive advantage. At the same time, that which is sustained concerns the company as well [24]. Much progress has been made in these three quadrants. An example is The Sustainable MBA [25].

The starting point for these three quadrants is similar to that of Management Education curriculanamely, management disciplines and an overarching concern for the pursuit of corporate competitive advantage. In general, the integration of sustainability in these three forms has been incrementalnot radical.

However, progress toward the integration of these three quadrants faces several shortcomings. The first one is the lack of deeper questioning of business education, which has been criticized from several standpoints over the last decade. One critique was put forward by Ghoshal [7] in a posthumously published article in which he highlighted the domination of theoretical science-like knowledge over practice and the promotion of University of Chicago ideology in Management curriculum. This curriculum, he stated, has led to the promotion of a negative representation and a deterministic vision of human behavior, and the prevalence of the ideology that favors shareholder value over value 
creation for other stakeholder groups. The domination of this short-term and potentially destructive ideology is far from being compatible with that of a sustainable world.

None of these three forms of integration (discipline based, application based, and strategic) rely on an adaptive approach to integration: they promote the view that sustainability needs to be "added on" to existing curricula without questioning the epistemology or/and purpose of Management Education curriculum. The starting points of these three forms of integration are the curricula per se; as such these forms do not themselves contribute to questioning entrenched assumptions related to Management Education [26,27].

A second set of critiques concerns the role of Management Education in contributing to the idea of a sustainable world. The argument that the current late capitalist economic system is not ecologically sustainable and increases social, economic, and cultural inequalities is not new (see [28,29], among others). Recent critiques of Management Education have highlighted the roles of Business Schools in reproducing and amplifying conditions for un-sustainability through the current form of Management Education [30]. Research in Management has marginally investigated how management and organizations could contribute to building more resilient and innovative social, environmental, and economic systems [31].

The fourth quadrant concerns systemic integration. It refers to inter-disciplinarity and a shift of analytical focus from competitive and business organizations to the conditions for sustainability in an economic-social-ecological system. This systemic integration frames the issue of sustainability as an issue of the general sustainability of the social-economic-ecological system by raising questions such as "How does one make social-ecological-economic systems more sustainable?", "How does one increase the resilience of systems?", and "How does one foster social or institutional innovation as possible sets of solutions for sustainability challenges?"

While the first three forms of integration are incremental as they add specific sustainability-related aspects to existing curricula, this fourth form is radical, given that its starting point is neither the existing Management Education curriculum nor the traditional scope of analysis of Business Education - namely, the competitive advantage of the business organization. Rather, this fourth form of integration is based on the premise that what are most important are the interactions between human societies and the biosphere in which business and non-business organizations operate. In addition, while the three first forms of integration are concerned with instrumental, , and short-term effects, the fourth form of integration aims to build connections and to train students and managers to think, operate, and feel differently.

\section{Conclusions}

This chapter has identified four forms of integrating sustainability into Management curriculum based on epistemological dimensions (Management mono-disciplinarity vs. Management interdisciplinarity) and also on the unit of analysis (firm centered $v s$. broader-system centered). While three of these forms are incremental forms of integration, the fourth form is radical. This concluding section identifies the limitations and implications for Management educators interested in designing courses in business sustainability. 
This article has the following limitations. First, this paper focuses on the curriculum itself and does not connect with other components or dimensions of students' educational experience, such as sustainable campus initiatives. Second, this paper does not focus on Management Education approaches or methods, such as case teaching, problem-based learning or traditional teaching approaches. Third, this paper does not address the role of the Management instructor or educator.

Implications for the design of Management Education modules, courses, and programs are the following. The framework introduced here aims to be used as a heuristic for evaluating a curriculum. It also is meant to be a way of mapping what is being done, what more could be done, and what needs to be strengthened or added to a given curriculum in matters of sustainability in Management Education curriculum. A lot of effort has been dedicated over the last decade to creating elaborate management teaching material and programs on sustainability. It is our hope that this simple framework will contribute to taking stock of what has been achieved and what needs to be done on the road ahead in order to achieve conditions for a sustainable world. Management Education is part of the sustainability problem; it could become part of the solution as well.

\section{Conflict of Interest}

The author declares no conflict of interest.

\section{References and Notes}

1. Gordon Rands, and Mark Starik. "The short and glorious history of sustainability in North American Management Education." In Management Education for Global Sustainability. Edited by Charles Wankel and James A.F. Stoner. Charlotte: Information Age Publishing, 2009, 19-49.

2. Charles Wankel, and James A.F. Stoner. Management Education for Global Sustainability. Charlotte: Information Age Publishing, 2009.

3. Denise Springett, and Kate Kearins. "Special Issue: Educating for Sustainability: An imperative for action." Business Strategy and the Environment 14 (2005): 143-45.

4. Mark Starik, Gordon Rands, Marcus Arnold, and Tom Clar. "In Search of Sustainability in Management Education." Academy of Management Learning and Education 9 (2010): 377-83

5. UNESCO. Educating for a Sustainable Future: A Transdisciplinary Vision for Concerted Action. Paris: UNESCO, 1997.

6. Paul Ottossonl, and Ben Samuelsson. Gothenburg Recommendations on Education for Sustainable Development. Göteborg: Centre for Environment and Sustainability, 2008.

7. Sumantha Ghoshal. "Bad management theories are destroying good management practices." Academy of Management Learning and Education 4 (2005): 75-91.

8. World Commission on Environment and Development. Our Common Future. New York: United Nations, 1987.

9. Mark Starik, and Gordon P. Rands. "Weaving an integrated web: Multilevel and multisystem perspectives of ecologically sustainable organizations." Academy of Management Review 20 (1995): 908-35

10. Bobby Banerjee. Who sustains whose development? Sustainable development and reinvention of nature. Organization Studies 24 (2003): 143-80. 
11. Zygmunt Bauman. Consuming Life. Cambridge: Polity Press, 2007.

12. Zygmunt Bauman. Does Ethics Have a Chance in a World of Consumers? Cambridge: Harvard University Press, 2008.

13. Lucie Sauvé. "Environmental education between modernity and postmodernity: Searching for an integrating educational framework." Canadian Journal of Environmental Education 4 (1999): 9-35.

14. Henry Mintzberg. Managers Not MBAs. San Francisco: Berrett-Koehler Publishers, 2004, 462

15. Henry Mintzberg, Robert Simons, and Kamal Basu. "Beyond selfishness." MITSloan Management Review 44 (2002): 67-74.

16. Warren Bennis, and Jonh O’Toole. "How business schools lost their way." Harvard Business Review 83 (2005): 96-104.

17. Charles Ferguson. Inside Job. Oxford: OneWorld Publications, 2010.

18. José Félix Lozano. "Educating Responsible Managers: The Role of University Ethos." Universitat Politecnica de Valencia, 2012, unpublished manuscript.

19. Jean Pierre Béchard. "L'intégration du curriculum en gestion: Vingt ans de recherche." In Cahiers des leçons inaugurales. Montreal: HEC Montréal, 2009, 49 pages, unpublished manuscript.

20. Emmanuel Raufflet, Denis Dupré, and Odile Blanchard. "Training managers for sustainable development: The lens of three practitioners." In Management Education for Global Sustainability, A Volume in Management Education and Development. Edited by Charles Wankel and James A.F.Stoner. Charlotte: Information Age Publishing, 2009, 377-93.

21. Robert A. Giacalone, and Kenneth R. Thompson. "Special issue on ethics and social responsibility: Introduction." Academy of Management Learning and Education 16 (2006): 261-65.

22. Richard Déry. "Enjeux et controverses épistémologiques dans le champ des sciences de l'administration." Revue canadienne des sciences de l'administration 9 (1992): 1-12.

23. Emmanuel Raufflet, and Consuelo Garcia de la Torre. "A la recherche du Pérou: Un regard sur les études organisationnelles péruviennes (1960-2000)." Management International 9 (2005): 61-75.

24. Bob Willard. The Next Sustainability Wave. Gabiola Island: New Society Publishers, 2004

25. The Sustainable MBA: The Manager's Guide to Green Business. Available online: http://www.thesustainablemba.com/ (accessed on 10 April 2013).

26. Lucie Sauvé. "Pour une recherche critique en éducation relative à l'environnement." In $L a$ recherche en éducation, la personne et le changement social. Edited by Corinne Baudoux and Marc Anadon. Working Paper 23. Les Cahiers du LABRAPS, Laboratoire de recherche en administration et politiques scolaires, Université Laval. Québec-City: Université Laval, 1997, 103-22.

27. Lucie Sauvé. "L'éducation relative à l'environnement: Possibilités et contraintes." Connexion, la revue d'éducation scientifique, technologique et environnementale de l'UNESCO 27 (2002): 1-4.

28. Donella H. Meadows, Denise. L. Meadows, Jorgen Randers, and William W. Behrens, III. The Limits to Growth: A Report for the Club of Rome's Project on the Predicament of Mankind. New York: Universe Book, 1972.

29. Millennium Ecosystem Assessment. Available online: http://www.maweb.org/en/Synthesis.aspx (accessed on 18 July 2013). 
30. Ian Doyle, Wayne Visser, and Jem Bendell. "World review." Journal of Corporate Citizenship 41 (2011): 8-25.

31. Frances R. Westley, Brenda Zimmerman, and Michael Quinn Patton. Getting to Maybe. Toronto: Random House Canada, 2006.

(C) 2013 by the author; licensee MDPI, Basel, Switzerland. This article is an open access article distributed under the terms and conditions of the Creative Commons Attribution license (http://creativecommons.org/licenses/by/3.0/). 